\title{
POTRET KEMISKINAN DAN UPAYA PENANGGULANGANNYA MELALUI PROGRAM PERLINDUNGAN SOSIAL DI KAWASAN TERPENCIL BANYUWANGI SELATAN
}

\author{
Nur Hidayati \\ Institut Agama Islam Darussalam Blokagung Banyuwangi \\ Email: nurhidayati875@gmail.com
}

\begin{abstract}
This study aims to (1) identify portrait of poverty in the remote area of Erpach, (2) portrait of poverty in the remote area of Soponyono, (3) identify poverty reduction efforts through social protection programs. The approach used is a qualitative approach, the type of research uses qualitative descriptive type. The results of this study indicate that the factors that cause poverty in the Erpach and Soponyono regions are the first structural and cultural poverty, the two education age communities do not have school motivation because of the distance and the difficult terrain, the third is the low skills of the community to manage potential in the area, the fourth is the lack of public education, the fifth part of the community lives around the forest and the coast. The mitigation efforts, first held the FGD (Focus Group Discussion), the second carried out the SAS social protection program (Peer Care) in cooperation with the village government with the local government, thirdly the skills training in managing the potential of the region in cooperation with the Cooperative and UMKM Office (Micro Business, Small and Medium) Banyuwangi district, and all four education programs are obliged to learn to cooperate with the Education Office.
\end{abstract}

Keywords: Poverty, Social Protection Programs and Remote Areas

\begin{abstract}
Abstrak
Penelitian ini bertujuan untuk (1) mengidentifikasi potret kemiskinan di Kawasan terpencil Erpach, (2) potret kemiskinan di Kawasan terpencil Soponyono, (3) mengidentifikasi upaya penanggulangan kemiskinan melalui program perlindungan sosial. Pendekatan yang digunakan adalah pendekatan kualitatif, tipe penelitian menggunakan tipe deskriptif kualitatif. Hasil penelitian ini menunjukkan bahwa faktor-faktor penyebab kemiskinan di daerah Erpach dan Soponyono adalah pertama kemiskinan secara struktural dan kultural, kedua masyarakat usia pendidikan tidak memiliki motivasi sekolah karena jarak tempuhnya yang jauh dan medan yang sulit, ketiga rendahnya keterampilan yang dimiliki masyarakat untuk mengelola potensi daerah, keempat minimnya pendidikan masyarakat, kelima sebagian masyarakatnya hidup di sekitar hutan dan pesisir. Upaya-upaya penanggulangannya, pertama mengadakan FGD (Focus Group Discussion), kedua melaksanakan program perlindungan sosial SAS (Siswa Asuh Sebaya) kerja sama pemerintah desa dengan pemerintah daerah, ketiga pelatihan keterampilan dalam mengelola potensi daerah kerja sama dengan Dinas Koperasi dan UMKM (Usaha Mikro, Kecil dan Menengah) kabupaten Banyuwangi, dan keempat program pendidikan wajib belajar kerja sama dengan Dinas Pendidikan.

Kata Kunci: Kemiskinan, Program Perlindungan Sosial dan Kawasan Terpencil
\end{abstract}




\section{A. Pendahuluan}

Kemiskinan merupakan kondisi ketidakmampuan seseorang untuk memenuhi kebutuhannya sesuai dengan kehidupan yang layak. Kemiskinan memiliki ciri yang berbeda antar wilayah, perbedaan ini terkait pada kemiskinan sumber daya alam, sumber daya manusia dan kelembagaan setempat. Kemiskinan tumbuh sebagai bagian dari masalah dalam kehidupan masyarakat. Kemiskinan bukan hanya masalah individu dalam suatu negara tetapi menjadi masalah bangsa dalam rangka globalisasi dan sudah menjadi masalah makro. Untuk memungkinkan masyarakat paling miskin bertindak, perlu ada fasilitator yang memiliki sumber daya, kekuasaan, dan kemampuan untuk bertindak. Masyarakat yang paling miskin terjebak dalam situasi ketidakberdayaan karena kemiskinan ekonomi dan sosial yang ekstrim, sehingga sering kali menyempitkan, membunuh kesadaran, melemahkan, mengisolir, dan merapuhkan mereka (Chambers, dalam Ismi dan Marwanti. 2012).

Permasalahan kemiskinan yang cukup kompleks membutuhkan intervensi semua pihak secara bersama dan terkoordinasi karena penanganannya selama ini cenderung parsial dan tidak berkelanjutan. Peran dunia usaha dan masyarakat pada umumnya belum juga optimal. Kerelawanan sosial dalam kehidupan masyarakat yang menjadi sumber penting dalam pemberdayaan dan pemecahan akar permasalahan kemiskinan juga mulai luntur (Chambers. 2012).

Kemiskinan dan pengangguran merupakan masalah utama yang harus ditanggulangi pemerintah dalam jangka pendek maupun jangka panjang. Kemiskinan merupakan hal yang sangat komples karena menyangkut berbagai macam aspek, seperti hak untuk terpenuhinya pangan, kesehatan, pendidikan, pekerjaan dan sebagainya. Angka kemiskinan di Kabupaten Banyuwangi mengalami jumlah penurunan dari tahun ke tahun dan menduduki angka terendah ke-12 dari 36 Kabupaten diseluruh Jawa Timur yaitu setelah Kota Malang, Kota Batu, Kota Madiun, Kota Surabaya, Kota Mojokerto, Kabupaten Sidoarjo, Kota Blitar, Kota Pasuruan, Kota Probolinggo, Kota Kediri, Kabupaten Tulungagung, dan Banyuwangi. Angka kemiskinan di Kabupaten Banyuwangi pada Tahun 2010 mencapai 20,09\% dan terus mengalami penurunan hingga pada Tahun 2015 
Kabupaten Banyuwangi mempunyai angka kemiskinan 9,17\% (Badan Pusat Statistik Provinsi Jawa Timur. 2016).

Melihat gambaran kemiskinan di Kabupaten Banyuwangi, walaupun telah terjadi penurunan jumlah penduduk miskin secara konsisten, namun jumlah penduduk yang hidup di bawah garis kemiskinan dapat dikatakan masih cukup besar. Di samping itu banyak masyarakat hidup mengelompok sedikit di atas garis kemiskinan, mereka ini sering disebut dengan kelompok hampir miskin (near poor) dan merupakan kelompok masyarakat yang sangat rentan. Pada kelompok ini, sedikit saja terjadi guncangan ekonomi, maka kelompok hampir miskin tersebut dapat dengan mudah jatuh kembali hidup di bawah garis kemiskinan. Inilah persoalan utama yang terjadi pada tataran nasional.

Kawasan Erpach dan Soponyono merupakan suatu wilayah yang berada di Kabupaten Banyuwangi bagian selatan, jalan menuju daerah ini melewati hutan panjang dan jalan yang sangat sepi, jauh dari permukiman, jauh dari akses kantor Kecamatan dan perkotaan. Rendahnya sumber daya manusia di daerah-daerah tersebut, menyebabkan tingginya pengangguran dan putus sekolah karena terkendala perekonomian dan akses menuju perkotaan, sehingga mereka yang mempunyai keinginan untuk melanjutkan pendidikannya, mereka terkendala dengan akses yang terbatas dan tidak adanya pengarahan dari masyarakat sekitar, tetangga ataupun saudara. Kurang meratanya bantuan pendidikan juga dirasakan masyarakat Banyuwangi selatan yang berada di daerah Erpach dan Soponyono. Banyaknya angka putus sekolah terjadi karena masalah ekonomi dan akses yang sangat jauh dari perkotaan sehingga miskin informasi.

Pandangan masyarakat desa di daerah terpencil termasuk Erpach dan Soponyono cenderung lebih berorientasi pada hal materiil, yaitu lebih menyukai jika anak-anaknya bekerja membantu orang tua dari pada harus belajar di sekolah. Mungkin hal inilah yang menyebabkan masyarakat desa di daerah tertinggal sulit melepaskan anak-anak mereka untuk menuntut ilmu di tempat yang jauh. Mereka lebih suka melihat anak-anak mereka di rumah membantu orang tua di ladang, tambak atau sawah. Paradigma seperti inilah yang telah ada dalam diri mereka sejak lama dan sulit untuk dirubah. Bagi masyarakat pedalaman, yang berpencar, pendidikan belum merupakan prioritas karena anak-anak masih dipandang sebagai 
alat produksi bagi keluarga, perbedaan ini perlu dieliminir. Masyarakat di sana berpikir bahwa sekolah kurang berguna untuk wanita. Karena pada akhirnya wanita akan kembali ke dapur dan hanya bekerja sebatas mengurus rumah, suami dan anak-anak.

Dari latar belakang di atas, rumusan masalah yang dikaji dalam penelitian ini adalah: (1) Bagaimana potret kemiskinan di Kawasan terpencil Erpach?, (2) Bagaimana potret kemiskinan di Kawasan terpencil Soponyono?, (3) Bagaimana upaya penanggulangan kemiskinan di Kawasan terpencil Banyuwangi Selatatan melalui program perlindungan sosial?

\section{B. Landasan Teori}

1. Kemiskinan

Miskin didefinisikan sebagai ketidakmampuan berpartisipasi dalam bermasyarakat secara ekonomi, sosial, budaya, dan politik. Oleh karena itu bentuk kemiskinan tidak hanya unidimensi tetapi mencakup juga kemiskinan insani dan kemiskinan martabat (Lubis. 2004). Pendekatan kemiskinan yang dilakukan oleh BPS dalam menghitung garis kemiskinan berdasarkan pada ukuran pendapatan, di mana batas kemiskinan dihitung dari besarnya rupiah yang dibelanjakan per kapita sebulan untuk memenuhi kebutuhan minimum makanan dan bukan makanan. Mengenai kebutuhan makanan digunakan patokan 2100 kalori per hari, dan pengeluaran kebutuhan minimum bukan makanan meliputi pengeluaran untuk perumahan, sandang, serta aneka barang dan jasa. Sedangkan Sayogyo (2005), dalam menentukan garis kemiskinan menggunakan ekuivalen konsumsi beras per kapita. Tolok ukur yang digunakan untuk mengukur batas garis kemiskinan tersebut adalah pendapatan yang bernilai setara dengan $240 \mathrm{~kg}$ beras untuk penduduk di desa dan $360 \mathrm{~kg}$ beras di kota. Tingkat kemiskinan penduduk ditinjau dari segi pendapatan ini diukur dari pengeluaran kebutuhan dasarnya. Indikator yang digunakan untuk menyatakan kemiskinan berdasarkan pendekatan kebutuhan dasar adalah Head Count Index (HCI), yaitu jumlah dan persentase penduduk miskin yang berada di bawah garis kemiskinan (Lubis. 2004). Kemiskinan, dalam realitasnya selalu dilihat dari sudut ekonomi, dimana batasan kemiskinan adalah suatu kondisi di 
mana orang tidak memiliki harta benda atau mempunyai pendapatan di bawah batasan nominal tertentu (Mansour Fakih. 2001).

2. Penanggulangan Kemiskinan

Penanggulangan kemiskinan di berbagai negara berkembang sekarang inisecara umum telah mengakui adanya paradigma baru (Ul Haq. 2005). Bukti empiris di negara berkembang telah menunjukan bahwa pertumbuhan ekonomi masyarakat miskin jauh lebih rendah dibandingkan dengan laju pertumbuhan ekonomi sacara keseluruhan. Penanggulangan kemiskinan di era otonomi daerah mengandung pelajaran tentang peluang penanggulangan kemiskinan, baik dari bentuk lama yang disusun di pemerintahan pusat, maupun pola baru hasil susunan pemerintah daerah, mungkin juga disertai dukungan pemerintah pusat atau swasta di daerah (Kementrian Koordinator Bidang Kesejahteraan Rakyat, 2004). Otonomi daerah memungkinkan peningkatan penanggulangan kemiskinan karena menghadapi jarak spasial maupun temporal yang lebih dekat dengan penduduk miskin itu sendiri. Selain itu peluang tanggung jawab atas kegiatan tersebut berada di tangan pemerintah kabupaten dan kota, serta pemerintah desa. Berbagai kebijakan penanggulangan kemiskinan yang dikeluarkan dan diimplementasikan bertujuan untuk mengurangi jumlah masyarakat miskin di Indonesia.

3. Kawasan Terpencil

Daerah terpencil adalah daerah yang mendapat giliran terakhir untuk akses ke inovasi teknologi. Hal ini disebabkan oleh biaya pengiriman yang sangat tinggi. Distribusi ke daerah terpencil sangat rumit. Tidak ada kurir, pos atau agen pengiriman dan tempat penjualan teknologi di tempat-tempat ini. Semakin terpencil daerah tujuan, akan semakin mahal harga sebuah produk karena biaya transportasi yang tinggi. Meskipun begitu, masyarakat di daerah terpencil seperti itu, yang memiliki akses terbatas ke prasarana dasar seperti listrik dan air bersih, justru adalah orang-orang sangat memerlukan teknologi sederhana seperti lampu tenaga surya dan filter air. Karena itulah kami berfokus untuk menjangkau daerah terpencil. Daerah tertinggal merupakan daerah yang terisolir dari pembangunan yang sedang berjalan. Tidak hanya secara fisik 
mereka tertinggal namun juga dari cara berpikir masyarakatnya. Prinsip "banyak anak banyak rejeki” seakan telah menjamur dalam kehidupan mereka.

4. Program Perlindungan Sosial Kabupaten Banyuwangi

Pemerintah Kabupaten (Pemkab) Banyuwangi terus mendorong berbagai program perlindungan sosial untuk masyarakat miskin. Tidak hanya bersumber dari dana APBD, beragam program itu juga didorong dengan skema public private partnership (PPP) dengan melibatkan sektor swasta dan BUMN. Berbagai inovasi program penanggulangan kemiskinan dan perlindungan sosial tersebut membuat Pemprov Jatim memberi penghargaan "Pro-Poor Award 2014" untuk Banyuwangi yang diserahkan Gubernur Jatim Soekarwo kepada Bupati Abdullah Azwar Anas dalam acara puncak pencanangan Bulan Bhakti Gotong Royong (BBGRM) di kota Kabupaten Ngawi.

Bupati Banyuwangi Abdullah Azwar Anas mengatakan, perlindungan sosial dan pengentasan kemiskinan adalah muara dari semua program pembangunan di wilayahnya. Di Banyuwangi, terdapat 5 Peraturan Daerah, 8 Peraturan Bupati, 29 Keputusan Bupati, dan 1 Surat Edaran Bupati yang mengatur soal perlindungan sosial dan pengentasan kemiskinan. Hasilnya, tingkat kemiskinan bisa ditekan ke level 9,93 persen dari angka 20 persen pada sebelum 2010. "Kami siapkan pro-poor regulation yang nantinya tecermin pada APBD kami dengan konsep pro-poor budgeting. Konsep program pengentasan kemiskinan ini ada yang karitatif atau jangka pendek, tapi lebih banyak yang bersifat transformatif dan jangka panjang melalui pemberdayaan masyarakat, perluasan akses pendidikan, dan peningkatan kapasitas warga.

Bupati Banyuwangi Abdullah Azwar Anas membeberkan enam strategi penanggulangan kemiskinan di Banyuwangi, yaitu pengembangan sistem perlindungan sosial bagi penduduk miskin dan rentan miskin, peningkatan akses pelayanan dasar, pemberdayaan kelompok miskin, pembangunan inklusif, penguatan kelembagaan, dan reorientasi kebijakan. Terdapat sejumlah program perlindungan sosial di Banyuwangi. Di antaranya adalah program Banyuwangi Cerdas dengan anggaran Rp 8 miliar tiap tahunnya untuk memberikan beasiswa kepada siswa dan mahasiswa yang tidak mampu. Selain 
di kampus yang ada di Banyuwangi, mahasiswa juga dikuliahkan ke sejumlah kampus negeri di luar kota.

\section{Metode Penelitian}

Penelitian ini merupakan penelitian dengan pendekatan kualitatif. Pada penelitian ini menggunakan pendekatan survey. Jadi metode pengkajian yang digunakan di dalam penelitian ini adalah pendekatan kualitatif, sedangkan tipe penelitian ini menggunakan tipe deskriptif kualitatif. Waktu penelitian adalah selama enam bulan, yaitu mulai dari bulan Juli sampai bulan Desember 2017. Sedangkan lokasi penelitian adalah di kawasan terpencil Erpach dan Soponyono yang berada di Kecamatan Tegaldlimo Kabupaten Banyuwangi.

Penelitian dilakukan dengan menggunakan empat pendekatan yaitu: (1) observasi, (2) wawancara, (3) analisis dokumen dan (4) survey. Untuk memperoleh data yang diperlukan dalam penelitian ini, maka peneliti menggunakan beberapa teknik pengumpulan data, yaitu: pertama observasi adalah pengamatan atau penginderaan secara langsung terhadap suatu benda, kondisi, proses, atau perilaku alat pengumpul datanya di sebut panduan observasi dan sumber datanya berupa benda tertentu, kondisi tertentu, dan proses atau perilaku tertentu (Sukidin dan Mundir. 2005:218).

\section{Hasil}

1. Gambaran Umum Lokasi Penelitian

Kabupaten Banyuwangi secara administratif berada di sebelah utara berbatasan dengan Kabupaten Situbondo, sebelah timur Selat Bali, sebelah selatan Samudera Indonesia, dan sebelah barat berbatasan dengan kabupaten Jember dan Bondowoso. Letaknya yang strategis berada di ujung timur pulau jawa menjadikan daerah ini berjuluk "The Sunrise of Java", selain itu kabupaten Banyuwangi menjadi penghubung antara pulau Jawa dengan pulau Bali yang sebelumnya telah lebih dulu dikenal sebagai destinasi wisata Indonesia. Pengaruh posistif dari "kedekatan" Banyuwangi dan Bali, pada perkembangannya membuat Banyuwangi juga mengembangkan potensipotensi wisatanya melalui even-even berskala nasional bahkan internasional 
untuk mendongkrak masuknya wisatawan lokal maupun manca negara ke kota yang sebelumnya dikenal dengan kota pisang ini.

Sedangkan daerah Erpach terletak di dusun Paluagung desa Kendalrejo kecamatan Tegaldlimo kabupaten Banyuwangi. Er berarti "terpencil” makanya Erpach dinamakan Kawasan Terpencil. Riwayat tanah Erpach Paluagung adalah tanah bekas Perkebunan Kopi pada zaman Kolonial Belanda tahun 1925, di mana pada tahun 1930 datang sekelompok masyarakat dari Jawa Tengah datang ke Perkebunan Kopi Paluagung untuk mencari mata pencaharian sebagai buruh kasar, saat itu pula sekelompok masyarakat tersebut diterima sebagai pekerja kebun. Dalam gambar tersebut tampak jalan menuju daerah Erpach adalah jalanan yang belum beraspal dengan udara yang sangat terik di musim kemarau karena sangat sedikit pohon dan tumbuhan di kanankiri jalan sehingga mengesankan daerah ini sangat gersang.

Pada tahun 1930 jumlah penduduk yang menempati pada perkebunan kopi sejumlah 200 jiwa, pada tahap kedua yaitu 1942 datang lagi sekelompok masyarakat untuk mencari pekerjaan pada perkebunan kopi sebanyak 400 orang, sehingga pada tahun 1942 jumlah jiwa yang bekerja di Perkebunan kopi mencapai 600 jiwa, terdiri dari laki-laki dan perempuan. Satu tahun setelah Indonesia merdeka, perkebunan mengalami bangkrut, sehingga pemilik kebun meninggalkan tanpa ada berita. Gambaran pemukiman masyarakat Erpach yang mayoritas menggantungkan hidupnya pada hasil hutan dan rendahnya tingkat pendidikan yang menjadi penyebab sulitnya mereka dapat mengembangkan potensi ekonominya.

Dalam beberapa tempat, masih terdapat bekas bongkaran bangunan besaran yang terletak di tengah tanaman hutan jati dan masih adanya sakalsakal yang tahu masalah asal usul tanah Erpach Paluagung. Pada tahun 1971 hingga sekarang tanah bekas Erpach oleh Kepala Desa Kendalrejo, dikenakan wajib pajak, dengan bukti SPPT pada masing-masing KK.

Badan Pertahanan Nasional Republik Indonesia, Kantor Pertahanan Kabupaten Banyuwangi Provinsi Jawa Timur mengeluarkan surat keterangan status tanah Erpach No.08/Erpach/V/2013 bahwa: (1) berdasarkan data di Kantor Pertahanan Kabupaten Banyuwangi di Desa Grajakan (sekarang Desa 
Kendalrejo, Kecamatan Tegaldlimo) di dalam Gouvenement Besluit tanggal 18-12-1916 No.10, Zie Meetbrief (Surat Ukur) tanggal 30-08-1916 No.6485 atas tanah Erpach Verponding No.754 seluas 156,2649 Ha tertuang dalam Verkregen Bii Akte tanggal 06-07-1917 No.128 tercatat atas nama GOUVERNEMENT VAN NED INDIE (Gradjagan), (2) atas tanah tersebut selanjutnya terjadi mutasi sebagai berikut: pada tanggal 29-04-1920 tercatat atas nama IE A SING, pada tanggal 20-11-1923 tercatat atas nama LIAP HOI, pada tanggal 17-09-1926 tercatat atas nama MAATSCHAP SING HWAT KONGSIE. Dan sampai saat ini belum ada perubahan atau mutasi atas tanah bekas Hak Erpach Verpending No.754 tersebut.

Sedangkan daerah Soponyono terletak di dusun Gladak Kembar desa Purwoagung, kecamatan Tegaldlimo kabupaten Banyuwangi. Derah ini masuk dusun Gladak Kembar walau keberadaan derah ini kurang lebih 2 km dari Kantor Desa Purwoagung. Di daerah Soponyono terdapat 313 jiwa terdiri dari laki-laki dan perempuan, daerah ini berada di pertengahan persawahan.

2. Temuan Penelitian

a. Faktor-faktor Penyebab Kemiskinan di Erpach

1) Kemiskinan kultural dan struktural

Masyarakat Erapch adalah masyarakat yang miskin secara kultural dan struktural. Hal ini sesuai dengan hasil observasi dan wawancara dengan penduduk sekitar. Diantaranya yaitu informasi dari Sekretaris Desa Kendalrejo:

"Masyarakat Erpach itu jarang bergaul dengan masyarakat lain, mereka cenderung tertutup, sulit diajak mandiri secara ekonomi, mereka lebih suka menggantungkan kebutuhan hidupnya pada hasil hutan, sehingga secara kultur mereka miskin, sedangkan daerahnya yang merupakan kawasan Perhutani semakin meneguhkan mereka untuk hidup terisolir dari masyarakat luas, jadilah mereka termiskinkan juga secara struktur”.

Dalam pengamatan peneliti, kehidupan masyarakat Erpach memang terkesan memisahkan diri dari masyarakat luas, hal ini juga ditunjang dengan wilayahnya yang jauh dari pemukiman warga serta medan jalan yang sulit dilalui, sehingga akses bersosialisasi dengan masyarakat menjadi terputus. 
Kemiskinan dibagi menjadi dua yaitu kemiskinan kultural dan struktural. Kemiskinan kultural merupakan kemiskinan yang pada umumnya diakibatkan oleh mental atau nilai-nilai yang dianut seseorang, yakni: malas bekerja, mudah menyerah pada nasib dan kurangnya kerja keras dan sebagainya untuk memperbaiki tingkat kesejahteraannya meskipun ada usaha dari pihak lain untuk membantunya. Dalam hal ini mereka yang terjerat dalam kemiskinan kultural cenderung menganggap kemiskinan merupakan sebuah nasib. Mereka lebih suka bekerja sebagai peminta-minta atau mereka baru bekerja sambilan apabila ada yang memerlukannya. Sikap malas ini menyebabkan kecenderungan untuk menggantungkan hidupnya kepada orang lain. Selain itu, pola hidup konsumtif yang menyebabkan besarnya pengeluaran dibandingkan pendapatan juga dapat menyebabkan terjadinya kemiskinan ini.

Mereka yang termasuk dalam jeratan kemiskinan struktural adalah mereka yang kurang mendapatkan akses untuk mendapat pendidikan yang berkualitas dan pekerjaan yang layak. Seperti contoh adalah buruh tani, pemulung, penggali pasir dan mereka yang tidak terpelajar dan tidak terlatih. Berbeda dari kemiskinan kultural, pihak yang berperan besar yang menyebabkan kemiskinan struktural adalah pemerintah, karena pemerintah yang memiliki kekuasaan dan kebijakan cenderung membiarkan masyarakat dalam kondisi miskin, kurangnya keseriusan untuk mengeluarkan kebijakan yang tepat untuk menaikkan kualitas pendidikan dan pekerjaan yang layak.

2) Masyarakat usia pendidikan tidak memiliki motivasi sekolah karena jarak tempuhnya yang jauh dan medan jalan sulit

Mayoritas masyarakat tidak memiliki pendidikan yang layak, diantara alasannya adalah jarak tempuh lokasi pendidikan yang jauh dan medan jalan yang sulit ditempuh. Hal ini sesuai wawancara dengan Bapak Suminto Utomo, Kepala Dusun Paluagung yang bertepatan rumahnya ada di daerah Erpach sebagai berikut:

"Sebenarnya banyak yang minat sekolah tapi karena jarak sekolahnya yang jauh dan jalannya cukup sulit dilalui, sehingga 
sering terlambat datang ke sekolah, lalu kena marah Guru. Awalnya kondisi ini juga membuat pihak sekolah menjemput mereka yang berinat sekolah, tetapi kendalanya adalah seringkali mobil penjemputnya rusak akibat jalannya yang jelek, akhirnya pihak sekolah tidak mau menjemput lagi, sehingga masyarakat tidak berminat sekolah lagi".

Sesuai pengamatan peneliti, kondisi jalan yang rusak parah, apalagi jika musim hujan memang sangat menghawatirkan para orang tua untuk menyuruh anaknya berangkat sekolah, sedangkan mereka juga membutuhkan bantuan anak-anaknya mencari kerang di tepi pantai untuk kecukupan hidupnya.

3) Rendahnya keterampilan yang dimiliki masyarakat untuk mengelola potensi daerah

Keterampilan yang rendah juga dimiliki oleh masyarakat daerah Erpach. Hal ini sesuai wawancara dengan Bapak Jarianto, salah satu penduduk daerah Erpach tepatnya warga masyarakat RT 34, sebagai berikut:

"Tanah di daerah ini sangat sulit mencari air yang bagus untuk irigasi pertanian, sehingga tanaman yang dijumpai adalah jagung, cabe rawit dan kedelai, itupun kalau musim kemarau tidak bisa diharapkan hasil panennya bisa baik, karena ya itu tadi keterbatasan air, sedangkan penduduk lainnya lebih suka mengumpulkan kayu bakar untuk dijual maupun digunakan untuk keperluan sendiri”.

Hasil wawancara tersebut menegaskan bahwa masyarakat Erpach memang tidak kreatif dan cenderung menggantungkan hasil hutan untuk mencukupi kehidupannya. Mereka perlu untuk diberikan keterampilan dalam mengolah hasil hutan agar bisa memberdayakan mereka dan membangun kemandirian mereka secara ekonomi.

4) Minimnya pendidikan masyarakat

Di daerah ini hanya dijumpai satu Lembaga Pendidikan Taman Kanak-Kanak dan satu Sekolah Dasar. Jadi kebanyakan anak-anak di daerah Erpach hanya lulusan Sekolah Dasar dan jarang yang melanjutkan ke tingkat atasnya. Karena jarak tempuh menuju Sekolah Menengah Pertama (SMP) yang terdekat dengan daerah Erpach 
kurang lebih sejauh $15 \mathrm{~km}$. Ada banyak harapan dari masyarakat daerah Erpach yang hidupnya di kawasan Perhutani dengan hanya memiliki hak guna bukan hak milik tersebut agar di daerah ini ada perhatian dari pemerintah daerah, sehingga masyarakat bisa mengenyam pendidikan yang layak dan bermanfaat untuk meningkatkan taraf hidupnya. Hal ini seperti penuturan Bapak Sukardi, HIPA Dusun Paluagung.

"Masyarakat tersebut (Erpach) hakikatnya masih punya keinginan menyekolahkan anak-anaknya, tapi mereka lebih berharap pemerintah mau menyediakan fasilitas pendidikan di daerah mereka, selain karena mudah ditempuh juga akan lebih banyak kesempatan mereka untuk minta bantuan kepada anak-anaknya setelah sekolah dalam pekerjaan mereka memanfaatkan hutan dan membantu mencari ikan dan kerang di pesisir pantai."

5) Masyarakatnya hidup di daerah pesisir

Sebagian masyarakat Erpach ada yang hidup di daerah pesisir, jadi pekerjaan mereka adalah sebagai nelayan tradisional. Berikut adalah wawancara peneliti kepada penduduk Erpach di daerah pesisir.

"Nelayan itu adalah pekerjaan yang tidak tetap artinya tergantung musim, ketika tidak musim ikan biasanya disebut musim paceklik, mereka bekerja serabutan. Akibatnya pendapatannya tidak pasti dan tidak dapat memenuhi kebutuhan sehari-hari, sehingga keluarga nelayan mengikutsertakan istri dan anak-anaknya untuk bekerja agar dapat membantu mencari penghasilan tambahan daripada disuruh bersekolah terutama anak-anak perempuan mereka, menurut mereka orang perempuan tidak penting sekolah tinggi karena nantinya akan kembali ke dapur".

Dari pengamatan peneliti dilihat dari kondisi dan fasilitas pemukiman nelayan di Soponyono sangatlah memprihatinkan, rumah tidak permanen dengan lantai tanah, seringkali dijumpai rumah tidak layak huni dan tidak memiliki fasilitas MCK. Kondisi yang demikian menyebabkan lingkungannya sering rawan terserang penyakit.

b. Faktor-faktor Penyebab Kemiskinan di Soponyono

1) Kemiskinan kultural dan struktural

Masyarakat Soponyono adalah masyarakat yang miskin secara struktural. Hal ini sesuai dengan hasil observasi dan wawancara 
dengan penduduk sekitar. Diantaranya yaitu informasi dari Kepala Desa Kendalrejo:

"Masyarakat Soponyono yang menjadi buruh tani tetaplah menjadi buruh tani, begitu pula nelayan, pemulung, dan lain-lain. Mereka belum mampu memanfaatkan sumber-sumber pendapatan yang sebenarnya tersedia bagi mereka. Sedangkan daerahnya yang merupakan kawasan pinggiran hutan yang dikelilingi oleh persawahan yang luas semakin meneguhkan mereka untuk hidup terisolir dari masyarakat luas, jadilah mereka miskin secara struktur".

Dalam pengamatan peneliti, kehidupan masyarakat Soponyono memang terbatas sumber daya alamnya, rendah kualitas sumber daya manusianya dan rendah produktivitasnya. Suatu contoh mereka menanam ketela pohon di ladang yang sangat luas dan hasil panennnya bisa berton-ton. Mereka menjual ketela pohon dengan harga yang murah kepada pengepul, seharusnya mereka bisa mengolah ketela pohon itu menjadi berbagai jenis makanan yang daya jualnya lebih tinggi.

2) Masyarakatnya hidup di sekitar hutan

Masyarakat Soponyono hidup di sekitar hutan menunjukkan bahwa kehidupan mereka sangat tergantung pada sumber daya hutan dan hasil hutan lainnya yang diperoleh dan dijualnya. Hal ini sesuai wawancara dengan Bapak Atim, Ketua RT 27 Dusun Gladak Kembar sebagai berikut:

"Mereka hanya menggantungkan kehidupannya pada sumber daya hutan. Sementara sumber daya hutan yang menjadi andalan kehidupan mereka dieksploitasi secara besar-besaran oleh pengusaha hutan yang datang dari luar maupun oleh masyarakat di sekitar hutan itu sendiri. Dalam kegiatan eksploitasi sumber daya hutan tersebut, masyarakat Soponyono bertindak sebagai buruh tebang dan angkut dengan pendapatan yang terbatas, di mana untuk memenuhi kebutuhan sehari-hari pun serba pas-pasan".

Sesuai pengamatan peneliti, kemiskinan masyarakat Soponyono salah satunya disebabkan oleh sempitnya lahan yang digunakan untuk menjadi sumber dan modal usaha. Bahkan sebagian besar masyarakat 
Soponyono tidak memiliki lahan untuk usaha persawahan, perladangan maupun perkebunan.

3) Rendahnya keterampilan yang dimiliki masyarakat untuk mengelola potensi daerah

Keterampilan yang rendah tidak hanya dimiliki oleh masyarakat daerah Erpach, tetapi juga masyarakat daerah Soponyono. Keduanya yang tinggal di kawasan Perhutani dan jauh dari pemukiman warga tersebut memang tidak memiliki keterampilan yang baik dalam mengelola hutan, terbukti mereka hanya mengumpulkan kayu bakar dan menanam ketela pohon, padi, cabe rawit dan kedelai. Padahal di musim kemarau ketiga tanaman tersebut seringkali gagal panen, karena kurangnya air. Hal ini sesuai wawancara Bapak Mestari, Ketua RT 28 Dusun Gladak Kembar.

"Tanah di daerah ini sangat sulit mencari air yang bagus untuk irigasi pertanian, jadi masyarakat Soponyono menanam padi jika pada musim penghujan saja, sedangkan penduduk lainnya bahkan anak-anak lebih suka mengumpulkan kayu bakar untuk dijual maupun digunakan untuk keperluan sendiri”.

Hasil wawancara tersebut menegaskan bahwa masyarakat Soponyono memang tidak kreatif dan cenderung menggantungkan hasil hutan untuk mencukupi kehidupannya. Mereka perlu untuk diberikan keterampilan dalam mengolah hasil hutan agar bisa memberdayakan mereka dan membangun kemandirian mereka secara ekonomi.

4) Minimnya pendidikan masyarakat

Di daerah ini tidak dijumpai adanya sekolah, walaupun hanya lembaga pendidikan tingkat Taman Kanak-Kanak (TK), sangat ironi dengan perkembangan sekolah pada masyarakat umumnya. Padahal untuk bisa masuk ke daerah ini melewati persawahan yang sangat panjang dan memisahkan daerah ini dengan perkampungan penduduk sekitar. Ada banyak harapan dari masyarakat daerah Soponyono yang hidupnya di kawasan Perhutani ini ada perhatian dari pemerintah daearah untuk membangun sekolah, sehingga masyarakat bisa 
mengenyam pendidikan yang layak dan bermanfaat untuk meningkatkan taraf hidupnya. Hal ini seperti penuturan Bapak Sumarno, penduduk Soponyono.

"Masyarakat tersebut (Soponyono) hakikatnya masih punya keinginan menyekolahkan anak-anaknya, tapi mereka lebih berharap pemerintah mau menyediakan fasilitas pendidikan di daerah mereka, selain karena mudah ditempuh juga akan lebih banyak kesempatan mereka untuk minta bantuan kepada anakanaknya setelah sekolah dalam pekerjaan mereka memanfaatkan hutan. Hal ini tidak akan terjadi jika sekolahnya jauh”.

c. Upaya-upaya Penanggulangannya

1) Mengadakan FGD (Focus Group Discussion)

Kegiatan ini adalah upaya menghadirkan masyarakat daerah Erpach dan Soponyono serta pemerintah desa untuk mengetahui faktorfaktor yang menyebabkan kedua masyarakat daerah tersebut miskin, baik secara kultural maupun struktural. Selanjutnya mencari solusi alternatif untuk memberdayakan masyarakat tersebut dengan beberapa program, baik pelatihan maupun pendidikan yang bermanfaat untuk memberdayakan mereka untuk mengolah potensi daerahnya masingmasing.

2) Melaksanakan Program Perlindungan Sosial Siswa Asuh Sebaya kerjasama Pemerintah Desa dengan Pemerintah Daerah

Program ini telah dirilis oleh pemerintah daerah kabupaten Banyuwangi, maka sudah seyogyanya pemerintah desa meresponnya untuk memberdayakan masyarakat daerah Erpach yang selama ini belum sejahtera, secara pendidikan khususnya, dan berimbas pada kemampuan ekonomi yang rendah. Program Siswa Asuh Sebaya ini sangat baik bagi peningkatan kemauan dan kemampuan masyarakat dalam mendapatkan pendidikan yang layak dan dibutuhkan untuk meningkatkan taraf hidupnya. Diantara faktornya adalah relasi kesebayaan yang meminimalisir "sungkan" dan "enggan" yang dirasakan masyarakat karena telah tertinggal pendidikan, sehingga diharapkan masyarakat terpacu mengenyam pendidikan dan mampu beradaptasi dengan perkembangan zaman. 
3) Pelatihan keterampilan dalam mengelola potensi daerah kerjasama dengan Dinas Koperasi dan UMKM (Usaha Mikro, Kecil dan Menengah) kabupaten Bayuwangi

Pelatihan keterampilan dibutuhkan untuk memberikan bekal pada masyarakat sesuai dengan kemampuan dan potensi daerahnya agar bisa bernilai profit dan mampu mencukupi kebutuhan hidupnya, sehingga tidak hanya bergantung pada hasil hutan. Sedangkan hasil hutan jika tidak cerdas dalam pengolahannya seringkali hanya akan memperburuk keadaan. Maka dengan pelatihan keterampilan kerjasama dengan Dinas Koperasi dan UMKM diharapkan masyarakat Erpach termotivasi untuk mandiri secara ekonomi, diantaranya dengan melatih kemampuannya semakin terampil dalam mengolah potensi daerahnya yang hasilnya turut dibantu oleh dinas Koperasi dan UMKM dalam pemasarannya.

4) Program Pendidikan wajib belajar kerjasama dengan Dinas Pendidikan.

Pendidikan wajib belajar yang selama ini menjadi program wajib pemerintah pusat maupun daerah juga harus diterima oleh masyarakat Erpach. Jika selama ini masyarakat Erpach banyak yang enggan menempuh pendidikan tersebut diantara alasannya adalah karena jaraknya yang jauh dan medan jalannya yang cukup sulit, maka sangat baik jika di daerah ini disediakan tempat pelaksanaan wajar dikdas (wajib belajar pendidikan dasar) tersebut, meskipun misalnya secara kondisi fisik tidak bagus, tapi secara substantif tidak mengurangi nilainya. Dengan demikian, masyarakat Erpach yang terletak di kawasan terpencil mempunyai modal untuk hidup berkompetisi dengan masyarakat luar.

\section{E. Pembahasan}

Ada banyak faktor kemiskinan di Banyuwangi khususnya di daerah terpencil Erpach dan Soponyono. Sebelumnya kemiskinan itu dapat diartikan dimana seseorang sangat sulit untuk memenuhi kebutuhan hidupnya sehari-hari dikarenakan berbagai penyebab salah satunya adalah rendahnya tingkat pendapatan yang diperoleh. Dari temuan peneliti faktor-faktor kemiskinan di 
daerah Erpach dan Soponyono tidak begitu berbeda jauh karena kedua daerah ini sama-sama ada di perhutani.

Faktor-faktor penyebab kemiskinan di Erpach yaitu: (1) Kemiskinan secara kultural dan struktural, (2) Masyarakat usia pendidikan tidak memiliki motivasi sekolah karena jarak tempuhnya yang jauh dan medan jalan yang sulit, (3) Rendahnaya keterampilan yang dimiliki masyarakat untuk mengelola potensi daerah, (4) Minimnya pendidikan masyarakat, dan (5) Sebagian masyarakatnya hidup di pesisir. Sedangkan faktor-faktor penyebab kemiskinan di Soponyono yaitu: (1) Kemiskinan secara kultural dan struktural pula, (2) Masyarakatnya hidup di sekitar hutan, (3) Rendahnya keterampilan yang dimiliki masyarakat untuk mengelola potensi daerah, dan (4) Minimnya pendidikan masyarakat.

Pada penelitian ini upaya-upaya yang dapat dilakukan untuk menanggulangi kemiskinan di daerah Erpach dan Soponyono mengacu pada faktor-faktor penyebabnya adalah sebagai berikut: pertama mengadakan FGD (Focus Group Discussion), kedua melaksanakan Program Perlindungan Sosial SAS (Siswa Asuh Sebaya), karena program ini meraih penghargaan kompetisi inovasi pelayanan publik yaitu sebagai TOP 12 kategori terbaik Provinsi Jawa Timur tahun 2016. Penghargaan tersebut diserahkan langsung Gubernur Jatim Soekarwo kepada Bupati Banyuwangi Abdullah Azwar Anas.

Minimnya pendidikan memicu timbulnya kemiskinan dan tidak semua permasalahan pendidikan mampu ditangani oleh pemerintah daerah. Harapannya program SAS menjadi salah satu solusi untuk mengatasi keterbatasan tangan pemerintah dalam membiayai pendidikan masyarakat yang membutuhkan. Ketiga pelatihan keterampilan dalam mengelola potensi daerah bekerja sama dengan Dinas Koperasi dan UMKM (Usaha Mikro, Kecil dan Menengah), dan keempat program pendidikan wajib belajar kerja sama dengan Dinas Pendidikan. Pendidikan wajib belajar yang selama ini menjadi program wajib pemerintah pusat maupun daerah juga harus diterima oleh masyarakat Erpach dan Soponyono.

\section{F. Kesimpulan}

Berdasarkan temuan-temuan penelitian dapat disimpulkan sebagai berikut: Faktor-faktor Penyebab Kemiskinan di Erpach. Pertama, kemiskinan secara 
struktural dan kultural. Kemiskinan yang muncul di daerah Erpach ini awalnya secara terstruktur artinya ketidakmampuan masyarakatnya untuk bekerja bukan karena malas melainkan karena ketidakmampuan sistem dan struktur sosial dalam menyediakan kesempatan-kesempatan yang memungkinkan dapat bekerja. Tapi cara berfikir masyarakat Erpach yang menganggap pendidikan itu tidak terlalu penting apalagi bagi seorang wanita yang nantinya pasti akan kembali ke dapur. Itulah yang menjadikan munculnya kemiskinan secara kultural di kawasan terpencil Erpach. Kedua, masyarakat usia pendidikan tidak memiliki motivasi sekolah karena jarak tempuhnya yang jauh dan medan jalan sulit. Ketiga, rendahnya keterampilan yang dimiliki masyarakat untuk mengelola potensi daerah. Keempat, minimnya pendidikan masyarakat. Padahal pendidikan adalah hal yang sangat penting, pendidikan termasuk cara untuk membawa diri kita pada pengetahuan yang lebih baik dan positif. Kelima, sebagian masyarakatnya hidup di daerah sekitar pesisir.

Faktor-faktor Penyebab Kemiskinan di Soponyono yaitu pertama, kemiskinan secara struktural. Kedua, masyarakatnya hidup di sekitar hutan. Mereka hanya menggantungkan hidupnya pada hasil hutan untuk memenuhi kehidupan sehari-hari. Ketiga, rendahnya keterampilan yang dimiliki masyarakat sekitar untuk mengelola potensi daerah. Keempat, minimnya pendidikan masyarakat. Mereka enggan untuk menerima atau menciptakan ide-ide baru. Hal ini disebabkan karena kurangnya keterbukaan terhadap pengetahuan baru dan kurangnya kesadaran terhadap pentingnya pendidikan. Sebagian besar masyarakat Soponyono lebih mengutamakan keterampilan bekerja daripada kemampuan intelektual, sehingga jarang dari masyarakat Soponyono yang merasa perlu mengenyam pendidikan.

Upaya-upaya Penanggulangannya. Pertama, mengadakan FGD (Focus Group Discussion) dengan masyarakat Erpach dan Soponyono. Kedua, melaksanakan Program Perlindungan Sosial SAS (Siswa Asuh Sebaya) kerjasama Pemerintah Desa dengan Pemerintah Daerah. Ketiga, pelatihan keterampilan dalam mengelola potensi daerah kerjasama dengan Dinas Koperasi dan UMKM (Usaha Mikro, Kecil dan Menengah) kabupaten Bayuwangi.keempat, program Pendidikan wajib belajar kerjasama dengan Dinas Pendidikan. 


\section{G. Saran}

1. Bantuan Program Perlindungan Sosial dari Pemerintah Daerah bisa merata sehingga warga yang tidak mampu bisa melanjutkan pendidikannya.

2. Pendidikan itu sangatlah penting, jangan jadikan kemiskinan sebagai faktor utama putus sekolah.

3. Problem kemiskinan di masyarakat saat ini berbanding lurus dengan semakin bertambahnya jumlah penduduk Indonesia. Masalah yang terjadi di kota tidak terlepas karena adanya problem masalah yang terjadi di desa khususnya daerah-daerah terpencil, yaitu kurangnya sumber daya manusia yang produktif. Problem itu tidak akan menjadi masalah serius apabila pemerintah lebih fokus terhadap perkembangan dan pembangunan desa tertinggal dengan membuka lapangan pekerjaan di pedesaan sekaligus menerapkan desentralisasi otonomi daerah untuk mengembangkan potensinya menjadi lebih baik.

\section{Daftar Pustaka}

Agus Purwanto, Ewan. 2007. Mengkaji Potensi UKM untuk Pembuatan Kebijakan Anti- Kemiskinan di Indonesia. dalam Jurnal Ilmu Sosial dan Ilmu Politik. Volume 10, No. 3, Maret. Yogyakarta. Penerbit: Fisipol UGM ISSN 1410-4946

Bogdan, RC. and Biklen, SK. 1982. Qualitative Research for Education aa Introduction to Theori and Methods, London: allyu and Bacon

Badan Pusat Statistik Kabupaten Banyuwangi, Tahun 2016

Badan Pusat Statistik Provinsi Jawa Timur, Tahun 2016

Banyuwangikab.go.id

Chambers, dalam Ismi dan Marwanti. 2012. Kebijakan Penanggulangan Kemiskinan dan Kelaparan di Indonesia, dalam Jurnal AKK, Volume 1 No.1 September. Makassar. Penerbit: FKM-Universitas Hasanuddin.

Irfan Arif Siregar. 2014. Upaya Penanggulangan Kemiskinan Melalui Program Pembangunan Kampung Nelayan Indah. Jakarta. Universitas Indonesia.

Jajang W. Mahri. 2006. Kemiskinan di Indonesia, dalam Jurnal Pendidikan Ekonomi dan Koperasi, Volume 1, Nomor 1, Januari. Bandung-Jawa Barat Penerbit: Universitas Pendidikan Indonesia

Kementrian Koordinator Bidang Kesejahteraan Rakyat. 2004

Lubis. 2010. Budaya Kemiskinan di Masyarakat: Tinjauan Kondisi Kemsikinan dan Kesadaran Budaya Miskin, dalam Jurnal Ilmiah Fakultas Ilmu Sosial dan Ilmu Politik, Volume 1 Nomor 01. Penerbit: FISIP-Udayana Bali

Nano Prawoto. 2009. Jurnal penelitian Memahami Kemiskinan dan Strategi Penanggulangannya, Fakultas Ekonomi Universitas Muhammadiyah Yogyakarta 
Pasandaran. 1999. Kemiskinan dan Kesenjangan Sosial, dalam Jurnal SosisoKonsepsia, Volume 16/No.3, September-Desember 2011, Penerbit Pusat Penelitian dan Pengembangan Kesejahteraan Sosial (P3KS), Kementerian Sosal RI, Jakarta, 2011

Pemerintah Kabupaten Banyuwangi. 2012. Salah Satu Cara Putuskan Rantai Kemiskinan. http://www.banyuwangikab.go.id/berita-daerah/sas-salahsatu-cara-putuskan-mata-rantai-kemiskinan.html (Rabu, 16 Desember 2016)

PendidikanBanyuwangi.

http://pendidikan.banyuwangikab.go.id/files/SOP\%20SAS.pdf (Rabu, 16 Desember 2016)

Pemerintah Kabupaten Banyuwangi. 2012. SAS Salurkan Dananya untuk Kedipan Teman. http://www.banyuwangikab.go.id/berita-daerah/sas-salurkandananya-untuk-kediapan-teman-sebaya.html (Rabu,16 desember 2016)

Pemerintah Kabupaten Banyuwangi. 2014. Bupati Banyuwangi Salinan Keputusan Bupati Banyuwangi Nomor: 188/182/KEP/429.011/2014 tentang Program Siswa Asuh Sebaya. Banyuwangi

Sayogyo. 2005. Kebijakan Pembangunan yang Berpihak pada Masyarakat Miskin: Studi Pembangunan Masyarakat terhadap Program Pengentasan Kemiskinan Perkotaan di Kota Batam. Laporan Penelitian. Jakarta: Pusat Pengkajian Pengolahan Data dan Informasi Sekretariat Jenderal DPR RI

Tibyan. 2010. Analisis Program Penanggulangan Kemiskinan di Kabupaten Sragen, Program Magister Ekonomi dan Studi Pembangunan Konsentrasi Ekonomi Suberdaya Manusia dan Pembangunan. Surakarta .Universitas Sebelas Maret.

Ul Haq. 2006. Kemiskinan di Indonesia, dalam Jurnal Pendidikan Ekonomi dan Koperasi, Volume 1, Nomor 1, Januari. Bandung, Jawa Barat. Penerbit Universitas Pendidikan Indonesia. 